\title{
Effects of Ascorbic Acid as Antioxidant Semen Additive in Cryopreservation of Cross-bred Cattle Bull Semen
}

\author{
Padamveer Singh ${ }^{1}$, Sanjay Agarwal ${ }^{1 *}$, Harjyote Singh ${ }^{1}$, Satbir Singh $^{2}$, \\ Pawan Kumar Verma ${ }^{3}$, Mohd Shaheem Butt ${ }^{1}$ and Utsav Sharma ${ }^{1}$
}

\author{
${ }^{1}$ Divison of Veterinary Gynaecology \& Obstetrics, F.V.Sc. \& A.H., S.K.U.A.S.T.-J., R. S. \\ Pura-181102, Jammu, India \\ ${ }^{2}$ Frozen Semen Laboratory, U.T. of Jammu \& Kashmir, Hukkal, Jammu, India \\ ${ }^{3}$ Division of Veterinary Pharmacology and Toxicology, F.V.Sc. \& A.H., S.K.U.A.S.T.-J., R. S. \\ Pura-181102, Jammu, India \\ *Corresponding author
}

\section{A B S T R A C T}

\begin{tabular}{|l|}
\hline Ke y w o r d s \\
$\begin{array}{l}\text { Semen, Cattle bull, } \\
\text { Ascorbic acid, } \\
\text { Oxidative stress }\end{array}$ \\
\hline Article Info \\
\hline $\begin{array}{l}\text { Accepted: } \\
\text { 22 June 2020 } \\
\text { Available Online: } \\
\text { 10 July } 2020\end{array}$ \\
\hline
\end{tabular}

The present study was jointly undertaken at the Frozen Semen Laboratory, U.T. of Jammu \& Kashmir, Hukkal, Jammu and Division of V.G.O., F.V.Sc \& A.H., SKUAST- J, R.S.Pura, during the period between December 2017 and May 2018. This investigation was carried out with the objective to study the effect of antioxidant semen additive ascorbic acid on cryopreservation of semen. Semen samples $(n=10)$ from mature cattle bull stationed at Frozen semen laboratory, U.T. of Jammu \& Kashmir, Hukkal, Jammu, were used to evaluate the effect of ascorbic acid additive at post-dilution and at post thaw stage. The semen sample was extended with Tris-Egg-Yolk-Citric-acid-Fructose-Glycerol (TEYCAFG) extender and were split into two groups: Group 1: TEYCAFG without any additive/ control and group 2: TEYCAFG + Ascorbic acid (5mM). Progressive motility, live spermatozoa, acrosomal integrity, sperm abnormality, hypo-osmotic swelling test (HOST) was evaluated at both post-dilution and post-thaw stage. Whereas, oxidative stress tests viz. malondialdehyde (MDA), catalase (CAT) and superoxide dismutase (SOD) were evaluated at only post-thawed stage. Group 2 i.e. ascorbic acid group, showed significant $(\mathrm{p}<0.05)$ increased live spermatozoa, acrosomal integrity and HOST positive spermatozoa, while significant $(\mathrm{p}<0.05)$ decreased sperm abnormalities in post-thawed semen. In oxidative stress evaluation the MDA level was significantly $(\mathrm{p}<0.05)$ decreased, whereas, SOD levels significantly $(\mathrm{p}<0.05)$ increased in group 2 in comparison to control group. It was concluded that addition of ascorbic acid $(5 \mathrm{mM})$ as semen additive improves semen quality and minimize oxidative stress to the spermatozoa during cryopreservation of semen.

\section{Introduction}

The milk production in India was 187.7 Million Tonnes (MT) in year of 2018-19
(NDDB, 2020) in which contribution of Jammu and Kashmir (J\&K) is 254 MT. The cattle population in the country as per 2019 census were 192.5 million out of total bovine 
population (302.3 millions) in J\&K total cattle including cross-bred and indigenous were 1231 (in thousands). To meet the objective of sustainable milk production, special attention is required for improving the gene pool of the animals. The best proven way to improve gene pool is artificial insemination of the animals with frozen semen from superior bulls, thus it is only possible by making available sufficient number of frozen doses from superior bulls.

Now-a-days the bulls frozen semen has been widely used in artificial insemination (AI) but the results of conception is about 50 per cent. This might be due to freezing and thawing processes that leads to the generation of reactive oxygen substances (ROS) that impair post-thaw motility, viability, intracellular enzymatic activity, fertility and sperm functions (Aitken et al., 1998; Zhao and Buhr, 1995; White, 1993).

Oxidative stress is defined as a disturbance in the balance between the production of reactive oxygen species (ROS) and antioxidant defenses in the body. The cause of oxidative stress is considered as a major conducive factor to male infertility and decreased semen quality during the preservation process (Betteridge, 2000). Oxidative Stress installed at the level of tissues, organs or organelles is derived from the imbalance between the production and elimination of reactive oxygen species. Spermatozoa and seminal plasma possess an antioxidant system comprising taurine, reduced glutathione (GSH), glutathione peroxidase (GSH-Px), catalase (CAT), and superoxide dismutase (SOD) to prevent oxidative damage. However, this anti-oxidant capacity in sperm cells, due to the small cytoplasmic component that contains antioxidants to scavenge oxidants, is limited (Lapointe and Bilodeau, 2003; Aurich et al., 1997; Storey, 1997). Addition of antioxidants to the freezing media like ascorbic acid, catalase, caffeine, glutathione, taurine etc. in semen diluent prevent the damage induced by free radicals to spermatozoa during freezing as well as improves the fertility of the semen (Agarwal et al., 2004).

Ascorbic acid or Vit $\mathrm{C}$ concentration in seminal plasma exceeds 10 times more than that in blood plasma (364 compared with 40 $\mu \mathrm{mol} / \mathrm{L}$ ) (Tariq et al., 2015). It is an antioxidant substance, which is normally present in the epididymal fluid and seminal plasma of several species (Chinoy, 1972) which protects sperm from Reactive Oxygen Species (Buettner, 1993). Vit.C or ascorbic acid specifically reduces oxygen radicals, neutralizes ROS and regenerates other antioxidants system and helps in maintaining the genetic integrity of sperm cells by preventing oxidative damage to sperm DNA (Fragae et al., 1991).

Though few research using ascorbic acid as an semen additive has been previously reported but differences exists among ascorbic acid concentrations used, species, breed, dilutor composition, freezing method etc. but such research in the cross-bred bull semen of Jammu and Kashmir region is completely missing.

Thus keeping in view the aforesaid facts the present study was designed with the objective to evaluate the oxidative stress to the spermatozoa during cryopreservation of semen and the effects of ascorbic acid as semen additive.

\section{Materials and Methods}

The present study was jointly undertaken at the Frozen semen laboratory, U.T. of Jammu \& Kashmir, Hukkal, Jammu and Division of V.G.O., F.V.Sc \& A.H., SKUAST- J, R.S.Pura, during the period between 
December 2017 and May 2018. Semen samples $(n=10)$ were collected randomly from mature cattle bull stationed at Frozen semen laboratory, U.T. of Jammu \& Kashmir, Hukkal, Jammu, India $\left(32.73^{\circ} \mathrm{N}, 74.87^{\circ} \mathrm{E}\right.$, altitude $300 \mathrm{~m}$ ). Semen was collected twice a week from each bull by artificial vagina method. The semen ejaculates were initially evaluated for volume, mass activity, spermatozoa concentration and progressive motility. The ejaculates qualifying the minimum initial standards were further processed. After initial assessment of semen, the selected samples were extended with prewarmed $\left(37^{\circ} \mathrm{C}\right)$ Tris egg yolk citric acid fructose glycerol (TEYCAFG) extender so that each $\mathrm{ml}$ of extended semen contained at least $40 \times 10^{6}$ spermatozoa (Anel et al., 2003). After extension, the semen samples were divided into two parts. The first part was considered as group 1: TEYCAFG without any additive/ control and group 2: TEYCAFG + Ascorbic acid $(5 \mathrm{mM})$. The $\mathrm{pH}$ was adjusted within the range 7.2 to 7.4 . The semen samples were filled in $0.5 \mathrm{ml}$ capacity, polyvinyl straw (IMV, France). Equilibration was done in the cold handling unit maintained at $4^{\circ} \mathrm{C}$ for 4 hours. Freezing of the straws was done by programmable biofreezer (Digit Cool-530, IMV Technologies, France) with rate freezing from $4^{\circ} \mathrm{C}$ to $-10^{\circ} \mathrm{C} @ 5^{\circ} \mathrm{C}$, $10^{\circ} \mathrm{C}$ to $-100^{\circ} \mathrm{C} @ 40^{\circ} \mathrm{C},-100^{\circ} \mathrm{C}$ to $-140^{\circ} \mathrm{C} @$ $20^{\circ} \mathrm{C}$, after attainment of $-140^{\circ} \mathrm{C}$ temperature the straws were removed from the racks shifted to the pre-cooled goblets and plunged into liquid nitrogen and finally stored in liquid nitrogen tank where they were stored for definite period of time for future evaluation.

Total ejaculates $(n=10)$ were evaluated at two stages of the semen processing viz. postdilution and post thaw stage, for per cent progressive motility, live spermatozoa, acrosomal integrity, sperm abnormalities and hypo-osmotic swelling test. Whereas, only at post-thaw stage for oxidative stress test viz.
MDA, SOD and Catalase. Thawing of frozen semen was done at $37^{\circ} \mathrm{C}$ for 30 seconds.

Volume was measured by graduated collecting tube, mass activity was graded as described by Tomar et al., (1966). The concentration of the spermatozoa (millions/ml) was determined by Accucell photometer (IMV Technologies, France). Progressive motility, live spermatozoa and acrosome integrity were assessed as per Salisbury et al., (1978); HOST test was performed as described by Jeyendran et al., (1984); sperm abnormalities were assessed by Eosin-nigrosin stain with slight modification as described by Kumar (1993). Oxidative stress test viz. Malondialdehyde (MDA) was determined as described by Shafiq-urRehman (1984); Catalase as per Aebi (1983) and Superoxide dismutase (SOD) as described by Marklund and Marklund (1974). The results were analysed statistically using Analysis of Variance (ANOVA) (Snedecor and Cochran, 1989).

\section{Results and Discussion}

\section{Progressive motility}

The per cent progressive motility (Mean \pm SE) post-dilution and post-thawing in control group were $67.0 \pm 1.52$ and $48.0 \pm 2.49$; whereas in ascorbic acid group were $68.0 \pm$ 1.33 and $50.0 \pm 2.11$, respectively (Table 1.0 ). Perusal of the table (1.0) it was observed that the progressive motility (\%) differed none significantly between post-diluted control and ascorbic acid group as well as post-thaw control and ascorbic acid group.

In the present study in control group the per cent progressive motility of diluted semen (Table 1.0) was $67.0 \pm 1.52$ which was in agreement with the finding of Pathak et al., (1990) who reported per cent progressive motility as $65.30 \pm 1.20$ per cent in diluted 
semen of cattle bull. Whereas, in the control group per cent post thaw motility (Table 1.0) was in intermediate range in comparison to previous reports, which was less than reported by Kishore, 2009 (80.74); Pawshe et al.,2016 (61.7 \pm 2.6$)$; Uysal et al., 2007 (55.5 \pm 2.5$)$ and Ulfina and Raina, 2003 (55.34 \pm 1.02), while it was higher than reported by $\mathrm{Hu}$ et al., 2010 (36.88 \pm 1.53$)$ and Li et al., 2016 (14.7 $\pm 1.4)$.

The main reason for the decrease in the per cent post thaw progressive motility might be due to cryopreservation damage, ROS production and damage caused due to formation of ice crystal formation in mitochondria and Axomemes during cryopreservation that impairs sperm motility.

In the present study in ascorbic acid group the values of per cent progressive motility of diluted semen (Table 1.0) was $68.0 \pm 1.33$, which was in agreement with the finding of Mittal et al., (2014) who reported as $66.59 \pm$ 0.99 , while it was lesser than as reported by Rao et al., 2017 (78.05 \pm 0.02) and Sandeep et al., $2015(73.33 \pm 1.07)$. Whereas, per cent progressive motility of post thaw semen (Table 1.0) was $50.0 \pm 2.11$, which was higher than as reported by Rao et al., 2017 (46.83 \pm 0.01) and Sandeep et al., 2015 $(45.62 \pm 0.69)$ and lower than the finding of Sohail et al., $2015(62.73 \pm 2.80)$ and Mittal et al., $2014(56.75 \pm 0.75)$.

\section{Live spermatozoa}

The per cent live spermatozoa (Mean \pm SE) post-dilution and post-thawing in control group were $74.4 \pm 1.82$ and $50.8 \pm 1.17$; whereas in ascorbic acid group were 72.4 \pm 1.69 and 55.4 \pm 0.88 , respectively (Table 1.0). Perusal of the table (1.0) it was observed that the live spermatozoa (\%) differed non significantly between post-diluted control and ascorbic acid group, whereas, in post-thaw a significant $(\mathrm{p}<0.05)$ difference in live spermatozoa was observed between control and ascorbic acid group.

In the present study in the control group values of per cent live spermatozoa in diluted semen (Table 1.0) was $74.4 \pm 1.82$, which was in agreement with the findings of Keshava (1996) who reported 74.28 and Abdul-khalek et al., (2008) as $73.0 \pm 1.3$. Whereas per cent live spermatozoa in post thaw semen (Table 1.0) was $50.8 \pm 1.17$ which was less than reported by Bhalde et al.,1991 (57.64 \pm 0.78), Rao et al., 2017 (56.24 \pm 0.01$)$ and Abdul-khalek et al., 2008 (66-73 per cent). Decreasing proportion of live spermatozoa in post thaw semen may be due to cryo-damage caused to formation of ice crystals in extra and intracellular environment, increasing solute concentration (Mazur, 1984) and sperm susceptibility for freezing and thawing temperature, ROS production and lipid peroxidation (Bucak et al., 2008)

In the present study in ascorbic acid group the value of per cent live spermatozoa of diluted semen was $72.4 \pm 1.69$ which was in agreement with the findings of Sandeep et al., 2015 (76.21 \pm 1.01$)$. Whereas per cent live spermatozoa in post thaw semen (Table 1.0) was $55.4 \pm 0.88$ which was higher than the findings of Rao et al., 2017 (51.92 \pm 0.02$)$ and Sandeep et al., 2015 (48.21 \pm 0.75$)$, while lesser than the finding of Sohail et al., 2015 (60.43 \pm 3.17$)$.

\section{Acrosomal integrity}

The per cent acrosomal integrity (Mean \pm SE) post-dilution and post-thawing in control group were $79.7 \pm 1.52$ and $53.9 \pm 0.94$; whereas in ascorbic acid group were $78.7 \pm$ 1.78 and $64.3 \pm 2.42$, respectively (Table 1.0). Perusal of the table (1.0) it was observed that the acrosomal integrity (\%) differed non 
significantly between post-diluted control and ascorbic acid group, whereas, in post-thaw a significant $(\mathrm{p}<0.05)$ difference in acrosomal integrity was observed between control and ascorbic acid group.

In the present study in control group the values of per cent acrosomal integrity of diluted semen (Table 1.0) was $79.7 \pm 1.52$, which was in agreement with the finding of Lone et al., 2017 (80.17 \pm 3.26$)$, it was less than the finding of Rao et al., 2017 (85.77 \pm 0.01). Whereas, per cent acrosomal integrity of post thaw semen was $53.9 \pm 0.94$ which was in agreement with the finding of Rao et al., 2017 (56.24 \pm 0.01), however it was higher than the finding of Sandeep et al., 2015 (36.25 \pm 0.91) and Paudel et al., 2010 $(31.5 \pm 1.3)$. The decrease in acrosomal integrity at various stages may be due to loss of component of plasma membrane and loss of plasmalemma over entire acrosome during freeze- thawing.

In the present study in ascorbic acid group the values of per cent acrosomal integrity of diluted semen (Table 1.0) was $78.7 \pm 1.78$ which is lower than the finding of Rao et al., 2017 (85.77 \pm 0.01) and Mittal et al., 2014 $(81.75 \pm 0.47)$, while higher than the finding of Sandeep et al., 2015 (76.21 \pm 1.01). Whereas, per cent acrosomal integrity of post thaw semen was $64.3 \pm 2.42$ which was in agreement with the finding of Rao et al., (2017) who reported as $63.57 \pm 0.01$, while higher value was observed by Mittal et al., $2014(71.59 \pm 0.48)$ in their study and lower finding were observed by Sandeep et al., 2015

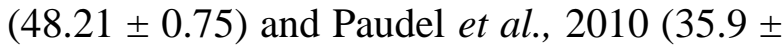
1.4).

\section{Sperm abnormalities}

The per cent sperm abnormalities (Mean \pm SE) post-dilution and post-thawing in control group were $7.2 \pm 0.63$ and $16.8 \pm 0.61$; whereas in ascorbic acid group were $6.8 \pm$ 0.83 and 13.2 \pm 0.79 , respectively (Table 1.0). Perusal of the table (1.0) it was observed that the sperm abnormalities (\%) differed non significantly between post-diluted control and ascorbic acid group, whereas, in post-thaw a significant $(\mathrm{p}<0.05)$ difference in sperm abnormalities was observed between control and ascorbic acid group.

In the present study in control group the values of per cent sperm abnormalities in diluted semen (Table 1.0) was $7.2 \pm 0.63$, which was in agreement with the finding of Rao et al., (2017) who reported as $7.28 \pm$ 0.02 , however it was higher than as reported by Mittal et al., 2014 (4.91 \pm 0.14 ), while it was lower than as reported by Gupta et al., 1990 (9.14 \pm 0.09$)$. Whereas, per cent post thaw sperm abnormalities was $16.8 \pm 0.61$ which was in agreement with the finding of Rao et al., (1999) who reported a range of $15.66 \pm 0.39$ to $16.75 \pm 0.37$, while it was higher than as reported by Mittal et al., 2014 (7.75 \pm 0.17), Sariözkan et al., 2009a (14.93 \pm 1.07) and Sariözkan et al., 2009b (15.0 \pm 1.1$)$, whereas lower than the finding of Gupta et al., 1990 (17.63 \pm 1.99$)$ and Rao et al., 2017 $(18.36 \pm 0.04)$.

In the present study in ascorbic acid group the value of per cent sperm abnormalities of diluted semen (Table 1.0) was $6.8 \pm 0.83$ which was in agreement with the finding of Rao et al., (2017) who reported as $6.78 \pm$ 0.03 , while lower value of per cent sperm abnormalities was observed in the finding of Mittal et al., 2014 (4.28 \pm 0.10$)$. Whereas, the values of post thaw semen was $13.2 \pm 0.79$ which was lower than the finding of Rao et al., 2017 (17.62 \pm 0.01$)$, while higher than the finding of Mittal et al., 2014 (6.84 \pm 0.12$)$.

\section{Hypo-osmotic swelling test (HOST)}

The hypo-osmotic swelling test positive spermatozoa per cent (Mean \pm SE) post- 
dilution and post-thawing in control group were $71.0 \pm 1.10$ and $45.4 \pm 0.93$; whereas in ascorbic acid group were $71.5 \pm 1.69$ and 49.4 \pm 0.87 , respectively (Table 1.0). Perusal of the table (1.0) it was observed that the hypoosmotic swelling test positive spermatozoa (\%) differed non significantly between postdiluted control and ascorbic acid group, whereas, in post-thaw a significant $(p<0.05)$ difference in hypo-osmotic swelling test positive spermatozoa was observed between control and ascorbic acid group.

In the present study in control group the per cent hypo-osmotic swelling test (HOST) positive spermatozoa of diluted semen (Table 1.0) was $71.0 \pm 1.10$ which was in agreement with the findings of Rao et al., (2017) who reported as $72.54 \pm 0.01$ and Lone et al., (2017) as $70.91 \pm 5.92$, however lower values was observed by Kumar et al., 2018 (62.11 \pm 0.89 ). Whereas, in post thaw semen the values of hypo-osmotic swelling test (HOST) positive spermatozoa (Table 1.0) was $45.4 \pm$ 0.93, which was agreement with the finding of Kumar et al., (2018) who reported as 45.94 \pm 1.33 and Sariözkan et al., (2009a) as 43.70 \pm 1.96 , while lower values were observed by Paudel et al., 2010 (39.6 \pm 1.3), Rao et al., 2017 (38.73 \pm 0.01) and Taraphdar, 1999 (36.52) and higher values was observed by Lone et al., $2017(51.30 \pm 4.43)$ and Sohail et al., 2015 (49.97 \pm 3.62). The structural changes produced in the post thaw sperm cells membrane are primarily linked to altered abilities for energy sourcing which later on influence both cellular metabolism and other sperm functions (Dziekonska et al., 2009; Gillan et al., 2004).

In the present study in ascorbic acid group the values of per cent HOST positive of diluted semen has been reported as $74.36 \pm 0.01$ in crossbred bull with $5 \mathrm{mM}$ of ascorbic acid (Rao et al., 2017) which was slightly higher than our present study value of per cent HOST positive i.e. $71.5 \pm 1.69$ (Table 1.0). In the present study the value of per cent HOST positive of post thaw semen of ascorbic acid group (Table 1.0) was $49.4 \pm 0.87$ which was slightly lower than the finding of Sohail et al., 2015 (51.37 \pm 3.98$)$, while higher than the finding of Rao et al., 2017 (42.27 \pm 0.02) and Paudel et al., $2010(41.0 \pm 1.3)$.

Table.1.0 The effect of ascorbic acid on different physio-morphological characteristics at postdilution and post-thaw semen of cross-bred bulls

\begin{tabular}{|l|l|l|l|}
\hline Parameter (\%) & Stage & Control & $\begin{array}{l}\text { Ascorbic acid } \\
(\mathbf{5 m M})\end{array}$ \\
\hline \multirow{2}{*}{ Progressive motility } & Post-dilution & $67.0 \pm 1.52^{\mathrm{a}}$ & $68.0 \pm 1.33^{\mathrm{a}}$ \\
\cline { 2 - 4 } & Post-thaw & $48.0 \pm 2.49^{\mathrm{a}}$ & $50.0 \pm 2.11^{\mathrm{a}}$ \\
\hline \multirow{2}{*}{ Live spermatozoa } & Post-dilution & $74.4 \pm 1.82^{\mathrm{a}}$ & $72.4 \pm 1.69^{\mathrm{a}}$ \\
\cline { 2 - 4 } & Post-thaw & $50.8 \pm 1.17^{\mathrm{a}}$ & $55.4 \pm 0.88^{\mathrm{b}}$ \\
\hline \multirow{2}{*}{ Sperosomal integrity } & Post-dilution & $79.7 \pm 1.52^{\mathrm{a}}$ & $78.7 \pm 1.78^{\mathrm{a}}$ \\
\cline { 2 - 4 } & Post-thaw & $53.9 \pm 0.94^{\mathrm{a}}$ & $64.3 \pm 2.42^{\mathrm{b}}$ \\
\hline \multirow{2}{*}{ HOST } & Post-dilution & $7.2 \pm 0.63^{\mathrm{a}}$ & $6.8 \pm 0.83^{\mathrm{a}}$ \\
\cline { 2 - 4 } & Post-thaw & $16.8 \pm 0.61^{\mathrm{a}}$ & $13.2 \pm 0.79^{\mathrm{b}}$ \\
\hline & Post-dilution & $71.0 \pm 1.10^{\mathrm{a}}$ & $71.5 \pm 1.69^{\mathrm{a}}$ \\
\cline { 2 - 4 } & Post-thaw & $45.4 \pm 0.93^{\mathrm{a}}$ & $49.4 \pm 0.87^{\mathrm{b}}$ \\
\hline
\end{tabular}

Values are given as mean \pm SE of 10 animals unless and otherwise stated

Values bearing different superscripts in a row differ significantly $(\mathrm{p}<0.05)$ 
Table.2.0 The effect of ascorbic acid on malondialdehyde (MDA), catalase (CAT) and superoxide dismutase (SOD) activity in post-thawed semen of cross-bred bulls

\begin{tabular}{|l|l|l|}
\hline Oxidative stress test & Control & Ascorbic acid (5mM) \\
\hline $\begin{array}{l}\text { MDA } \\
\left(\mathbf{n m o l} / \mathbf{1 0}^{\mathbf{8}} \text { Spermatozoa) }\right.\end{array}$ & $3.49 \pm 0.19^{\mathrm{a}}$ & $1.70 \pm 0.04^{\mathrm{b}}$ \\
\hline $\begin{array}{l}\text { CAT } \\
\left(\boldsymbol{\mu m o l} / \mathbf{1 0}^{\mathbf{8}} \text { Spermatozoa) }\right.\end{array}$ & $1.18 \pm 0.36^{\mathrm{a}}$ & $1.31 \pm 0.73^{\mathrm{a}}$ \\
\hline $\begin{array}{l}\text { SOD } \\
\left(\mathbf{U} / \mathbf{1 0}^{\mathbf{8}} \text { Spermatozoa) }\right.\end{array}$ & $0.95 \pm 0.06^{\mathrm{a}}$ & $1.31 \pm 0.05^{\mathrm{b}}$ \\
\hline
\end{tabular}

Values are given as mean \pm SE of 10 animals unless and otherwise stated

Values bearing different superscripts in a row differ significantly $(\mathrm{p}<0.05)$

\section{Malondialdehyde (MDA)}

The MDA levels (Mean \pm SE) post-thaw semen samples in control group and ascorbic acid group were $3.49 \pm 0.19$ and $1.70 \pm 0.04$, respectively (Table 2.0). Perusal of the table (2.0) it was observed that MDA levels in postthaw semen samples differed significantly $(\mathrm{p}<0.05)$ between control and ascorbic acid group.

The MDA level (nmol $\mathrm{H}_{2} \mathrm{O}_{2}$ produced/ $10^{8}$ spermatozoa) of post thaw semen in $712.1 \pm$ $49.1 \mathrm{nmol}$ MDA level $/ 10^{9}$ spermatozoa in crossbred bull (Paudel et al., 2010), $496.02 \pm$ $39.28 \mathrm{nmol}$ MDA level $/ 10^{9}$ spermatozoa in buffalo bull (Lone et al., 2017). In the present study MDA level (nmol $\mathrm{H}_{2} \mathrm{O}_{2}$ produced/ $10^{8}$ spermatozoa) in post thaw semen of control group (Table 2.0) was $3.49 \pm$ 0.19 which was lower than the value observed by Paudel et al., 2010 and Lone et al., 2017. The finding of other scientists could not be compared with our finding due to disparity in method of evaluation and units of measurement.

In the present study, the MDA level (nmol $\mathrm{H}_{2} \mathrm{O}_{2}$ produced/ $10^{8}$ spermatozoa) post thaw semen of ascorbic acid added group (Table 2.0) was $1.70 \pm 0.04$. In murrah buffalo bull with $2.5 \mathrm{mM}$ of ascorbic acid (Sandeep et al., 2015) observed the value of MDA level (concentration $\mathrm{ng} / 120$ million spermatozoa) in post thaw semen was $521.16 \pm 8.23$, which was higher than the present study finding, however, Paudel et al., 2010 observed the level of MDA production $\left(\mathrm{nmol} / 10^{9}\right.$ spermatozoa) in crossbred bull with $10 \mathrm{mM}$ concentration of ascorbic acid in post thaw semen which is higher than the value of our present investigation.

\section{Catalase}

The catalase levels (Mean \pm SE) post-thaw semen samples in control group and ascorbic acid group were $1.18 \pm 0.36$ and $1.31 \pm 0.73$, respectively (Table 2.0). Perusal of the table (2.0) it was observed that catalase levels in post-thaw semen samples differed non significantly between control and ascorbic acid group.

The catalase activity ( $\mu \mathrm{mol} \mathrm{H}_{2} \mathrm{O}_{2}$ decomosed/ $\mathrm{min} / 10^{8}$ spermatozoa) in post thaw semen has been reported as $1.16 \pm 0.82(\mathrm{U} / \mathrm{ml})$ in Qinchuan bulls (Zhao et al., 2015), $23.36 \pm$ 0.25 in rainy season, $24.25 \pm 0.30$ winter season and $24.22 \pm 0.56$ in summer season, respectively in buffalo bull (Sharma et al., 2016). In the present study catalase activity ( $\mu$ mol $\quad \mathrm{H}_{2} \mathrm{O}_{2}$ decomosed/ $\mathrm{min} / 10^{8}$ spermatozoa) in post thaw semen of control group (Table 2.0) was $1.18 \pm 0.31$ which was higher than finding of Zhao et al., (2015) 
whereas lower than the finding of Sharma et al., (2016). There was reduction in the catalase activity with the level of freezing. CAT activity reduced at post thaw stage when compared to pre freeze stage (Lone et al., 2017; Kadirvel et al., 2009). CAT is an enzymatic antioxidant found in all living organisms exposed to oxygen, which decomposes harmful peroxides and converts them into water and oxygen (Chelikani et al., 2004).

In the present study, the level of Catalase ( $\mu$ mol $\quad \mathrm{H}_{2} \mathrm{O}_{2}$ decomosed/ $\mathrm{min} / 10^{8}$ spermatozoa) in post thaw semen (Table 2.0) was $1.31 \pm 0.73$. The CAT activity reduced at post thaw stage when compared to pre freeze stage (Lone et al., 2017) and the reduction in the catalase activity also reported by Kadirvel et al., (2009).

\section{Superoxide dismutase (SOD)}

The SOD levels (Mean \pm SE) post-thaw semen samples in control group and ascorbic acid group were $0.95 \pm 0.06$ and $1.31 \pm 0.05$, respectively (Table 2.0). Perusal of the table (2.0) it was observed that SOD levels in postthaw semen samples differed significantly $(p<0.05)$ between control and ascorbic acid group.

The level of Superoxide dismutase (Unit/ $10^{8}$ spermatozoa) in post thaw semen have been reported as $104.02 \pm 26.34$ ( $\mu \mathrm{kat} / \mathrm{g}$ protein) in cattle bull (Sariözkan et al., 2009a), $7.2 \pm 1.8$ (U/g protein) in cattle bull semen (Sariözkan et al., 2009b), $3.50 \pm 0.19$ in cattle and $1.98 \pm$ 0.09 in buffalo bulls (Nair et al., 2006) and $0.16 \pm 0.03$ (units/mg protein) in buffalo bulls (Lone et al., 2017). The level of Superoxide dismutase (Unit/ $10^{8}$ spermatozoa) in present study in post thaw semen of control group (Table 2.0) was $0.95 \pm 0.06$ which was lower than the finding of Nair et al., (2006), however it was higher than the finding of
Lone et al., (2017). The mean SOD activity was reduced at post-thaw stages, when compared to pre-freeze. This decline in activity of SOD may be due to utilisation of SOD in neutralizing superoxides during freeze-thaw process SOD activity was reduced to $50 \%$ in Holstein Friesian bulls during cryopreservation (Bilodeau et al., 2000). Superoxide is a free radical which is converted to oxygen and hydrogen peroxide by the dismutation action of antioxidant enzyme superoxide dismutase (Tariq et al., 2015).

In the present study, the level of Superoxide dismutase (Unit/ $10^{8}$ spermatozoa) in post thaw semen of ascorbic acid added group (Table 2.0) was $1.31 \pm 0.05$. The mean SOD activity was reduced at post-thaw stages, when compared to pre-freeze. This decline in activity of SOD may be due to utilisation of SOD in neutralizing superoxides during freeze-thaw process SOD activity was reduced to $50 \%$ in Holstein Friesian bulls during cryopreservation (Bilodeau et al., 2000). Superoxide is a free radical which is converted to oxygen and hydrogen peroxide by the dismutation action of antioxidant enzyme superoxide dismutase (Tariq et al., 2015).

In conclusion, the present study with ascorbic acid $(5 \mathrm{mM})$ as the semen additive may be used for the cryopreservation of the semen. The parameters of semen quality improved in the ascorbic acid added cryopreserved semen in comparison of control group. The oxidative stress to the semen is also minimized after addition of the ascorbic acid. The in vitro fertility assessed by hypo-osmotic swelling test also indicates for the better quality and fertility in ascorbic acid group. However, the improved semen quality actually results in improved fertility rate in the cattle population should be validated. 


\section{References}

Abdel-Khalek, A.E., Aboul-Ela, S.M.B., Fawzy, A.Q. and Dandooush, E. 2008. Semen quality of holstein and buffalo bulls after filtration using sepahdex column. J. of Bio. Sci., 15: 91-97.

Aebi, H. 1983. Catalase. In: Methods in Enzymatic Analysis. Bergmeyer HU (ed). Academic Press, New York. pp 276-286.

Agarwal, A., Nallella, K.P., Allamaneni, S.S. and Said, T.M. 2004. Role of antioxidants in treatment of male infertility: An overview of the literature. Reprod. Biomed. Online, 8: 616-627.

Aitken, R.J., Gordon, E., Harkiss, D., Twigg, J.P., Milne, P., Jennings, Z. and Irvine, D.S. 1998. Relative impact of oxidative stress on the functional competence and genomic integrity of human spermatozoa. Bio. Reprod., 59(5): 1037-1046.

Anel, L., DePaz, P., Alvarez, M., Chamorro, C.A., Boixo, J.C., Manso, A., Gonzalez, M., Kaabi, M. and Anel, E. 2003. Field and in vitro assay of three methods for freezing ram semen. Theriogenology, 60(7): 1293 1308.

Aurich, J.E., Schonherr, U., Hope, H. and Aurich, C. 1997. Effect of antioxidants on motility and membrane integrity of chilled-stored stallion semen. Theriogenology, 48: 185192.

Betteridge, D.J. 2000. What is oxidative stress? Metabolism, 49(2):3-8.

Bhalde, R.M., Hukeni, V.B. and Deopaskas, V.L. 1991. Post thaw keeping quality of frozen bull semen maintained at room/ chilled temperature. Indian J. Anim. Reprod., 12(1): 87-90.

Bilodeau, J.F., Chatterjee, S., Sirard, M.A. and Gagnon, C. 2000. Levels of antioxidant defenses are decreased in bovine spermatozoa after a cycle of freezing and thawing. Mol. Reprd. Dev., 55(3): 282-288.

Bucak, M.N., Atessahin, A. and Yuce, A. 2008. Effect of anti-oxidants and oxidative stress parameters on ram semen after the freezethawing process. S. Rum. Res., 75(2): 128134.

Buettner, G.R. 1993. The pecking order of free radicals and antioxidants: Lipid peroxidation, $\alpha$ tocopherol and ascorbate. Arch. Biochem. Biophys., 300: 535-543.

Chelikani, P., Fita, I., and Loewen, P.C. 2004. Diversity of structures and properties among catalases. Cel. Mol. L. Sci., 61: 192-208.

Chinoy, N.J. 1972. Ascorbic acid levels in mammalian tissues and its metabolic significance. Comp. Biochem. Physiol. Part A: Comp Physiol., 42: 945-952.

Dziekońska, A., Fraser, L. and Strzeżek, J. 2009. Effect of different storage temperatures on the metabolic activity of spermatozoa following liquid storage of boar semen. J. Anim. and Feed Sci., 18: 638-649.

Fragae, C.G., Motchnik, P.A., Shigenaga, M.K., Helbock, H.J. and. Jacob, R.A. 1991. Ascorbic acid protects against endogenous oxidative DNA damage in human sperm. Proc. Nat. Acad. Sci., 88: 11003-11006.

Gillan, L., Maxwell, W.M.C. and Evans, G. 2004. Preservation and evaluation of semen for artificial insemination. Reprod. Fertil. Dev., 16: 447-454.

Griveau, J.F., Dumont, E., Renard, P., Callegari, J.P. and Le Lannou, D. 1995. Reactive oxygen species, lipid peroxidation and enzymatic defence system in human spermatozoa. J. Reprod. Ferti., 103: 17-26.

Gupta, H.P. Saxena, V.B. and Tripathi, S.S. 1990. A rapid method for evaluation of semen quality in bulls. Indian J. Anim. Sci., 60(3): 329-330.

Hu, J.H., Zan, L.S., Zhao, X.L., Li, Q.W., Jiang, Z.L., Li, Y.K. and Li, X. 2010. Effects of trehalose supplementation on semen quality and oxidative stress variables in frozenthawed bovine semen. J. Aim. Sci., 88(5): 1657-1662.

Jeyendran, R.S., Vander ven, H.H., Perez-Pelaez, M., Carbo, B.G. and Zanfeld, L.J.D. 1984. Development of an assay to assess the functional integrity of the human sperm membrane and its relationship to other semen characteristics. J. Repro. Fertil.,70: 219-228.

Kadirvel, G., Kumar, S. and Kumaresan, A. 2009. Lipid peroxidation, mitochondrial membrane potential and DNA integrity of spermatozoa in relation to intracellular reactive oxygen species in liquid and frozen-thawed buffalo semen. Anim. 
Reprod. Sci., 114(1): 125-134.

Keshava. P. 1996. Studies on seminal attributes and their association with expected breeding value of dairy bulls. M.Sc. Thesis, NDRI (Deemed University), Karnal, Haryana.

Kishore, A. 2009. Effect of taurine and other additives on preservability of bull semen, PhD thesis, NDRI, Karnal.

Kumar, H., Srivastava, S., Kumar, R., Kumar, R. and Singh, K.D. 2018. Effect of ascorbic acid on storage capacity of Murrah bull epididymal spermatozoa at refrigerator temperature. Int. J. Curr. Microbiol. App. Sci., 7: 4380-4386.

Kumar, M. 1993. Sexual behaviour pattern in sahiwal and murrah bulls. M.Sc. thesis, NDRI, Karnal.

Lapointe, J. and Biolodeau, J.F. 2003. Antioxidants defenses are modulated in the cow oviduct during the estrous cycle. Biol. Reprod., 68: 1157-1164.

Li, Y., Kalo, D., Zeron, Y. and Roth, Z. 2016. Progressive motility-a potential predictive parameter for semen fertilization capacity in bovines. Zygote, 24(1): 70-82.

Lone, S.A., Prasad, J.K., Ghosh, S.K., Das, G.K., Balamurugan, B. and Verma, M.R. 2017. Study on correlation of sperm quality parameters with antioxidant and oxidant status of buffalo bull semen during various stages of cryopreservation. Andrologia, 50(4): 1297.

Marklund, S. and Marklund, G. 1974. Involvement of the superoxide anion radical in the autoxidation of pyrogallol and a convenient assay for superoxide dismutase. Eur. J.Biochem., 47(3): 469-474.

Mazur, P. 1984. Freezing of living cells: mechanisms and implications. Am. J. of Physiol., 247: 125-142.

Mittal, P.K., Anand, M., Madan, A.K., Yadav, S. and Kumar, J. 2014. Antioxidative capacity of vitamin $\mathrm{E}$, vitamin $\mathrm{C}$ and their combination in cryopreserved Bhadavari bull semen. Vet. World, 7: 1127-1131.

Nair, S.J., Brar, A.S., Ahuja, C.S., Sangha, S.P.S. and Chaudhary, K.C. 2006. A comparative study on lipid peroxidation, activities of antioxidant enzymes and viability of cattle and buffalo bull spermatozoa during storage at refrigeration temperature. Reprod. Sci.,
96(1): 21-29.

NDDB. 2020 National Statistics. National Dairy Development Board, Anand, Gujarat. https://www.nddb.coop/information/stats.

Pathak, N., Bunzamin, B.R., Mohan, G. and Sahni, K.L. 1990. Libido in relation to other reproductive trait among the crossbred bulls. Indian J. Anim. Sci., 60(11): 52-54.

Paudel, K.P., Kumar, S., Meur, S.K. and Kumaresan, A. 2010. Ascorbic acid, catalase and chlorpromazine reduce cryopreservation-induced damages to crossbred bull spermatozoa. Reprod. domest. Anim., 45(2): 256-262.

Pawshe, M., Bibin, B., Becha ,Unnikrishnan, M.P., Harshan, H.M. and Ghosh, K.N.A. 2016. Bovine semen thawed at $28^{\circ} \mathrm{c}$ or $37^{\circ} \mathrm{C}$ can be used for ai till 90 min post-thaw. Thaw. Bo. sem., 32: 9-11.

Rao, K.B., Naidu, K.V., Singh, V., Rao, A.S. and Suresh, J. 1999. Studies on semen characteristic of Punganur bulls. Indian Vet. J., 51: 889-900.

Rao, T.K.S., Mohanty, T.K. and Bhakat, M. 2017. Assessment of antioxidants for preservation of crossbred bull semen in Tris based extender. Indian J. Anim. Res., 51(6): 993997.

Salisbury, G.W., Van Denmark, N.L. and Lodge, J.R. 1978. Principles and techniques of freezing spermatozoa. In: Physiology of Reproduction and Artificial Insemination of Cattle. Saliburg, G.A. (edt.), San Francisco: W.H Freeman Co. pp: 454-459.

Sandeep, P.S., Virmani, M. and Malik, R.K. 2015. Effect of vitamin $c$ on the seminal and biochemical parameters of Murrah buffalo bull semen during different stages of freezing. Haryana Veterinarian, 54(1): 1518.

Sariozkan, S., Bucak, M.N., Tuncer, P.B., Ulutas, P.A. and Bilgen, A. 2009a. The influence of cysteine and taurine on microscopicoxidative stress parameters and fertilizing ability of bull semen following cryopreservation. Cryobiology, 58(2): 134138.

Sariozkan, S., Bucak, M.N., Tuncer, P.B., Ulutas, P.A. and Bilgen, A. 2009b. influence of various antioxidants on microscopicoxidative stress indicators and fertilizing 
ability of frozen thawed bull semen. Acta Vet. Brno., 78: 463-469.

Shafiq-ur-Rehman. 1984. Lead induced regional lipid peroxidation in brain. Toxicology Letters, 21(3): 333-337.

Sharma, L., Pandey, V., Nigam, R., Saxena, A., Swain, D.K. and Yadav. B. 2016. Association of oxidative status and semen characteristics with seminal plasma proteins off buffalo semen. Iranian J. Vet. Res., 17(4): 226-230.

Snedecor, G. W and Cochran, W. G. 1989. Statistical Methods, $8^{\text {th }}$ edn., Iowa State University Press, USA.

Sohail, M.U., Shahzad, A.H., Iqbal, S., Shabbir, M.S., Iqbal, Z., Abbas, S. and Arshaad, T. 2015. Ascorbic acid inclusion in semen extender improves the post-thawed semen quality of Sahiwal cattle (Bos indicus). Pak. J. Zool., 47(6): 1571-1577.

Storey, B.T. 1997. Biochemistry of the induction and prevention of lipoperoxidative damage in human spermatozoa. Mol. Hum. Reprod., 3: 203-213.

Taraphdar, S. 1999. Studies on initial semen quality, freezability and fertility performance of Murrah buffalo bulls. M.Sc. thesis NDRI (Deemed Univrsity), Karnal, Haryana.

Tariq, M., Khan, M.S., Shah, M.G., Nisha, A.R., Umer, M., Hasan, S.M., Rahman, A. and Rabbani, I. 2015. Exogenous antioxidants inclusion during semen cryopreservation of farm animals. J. Chem. and Pharma. Res., 7(3): 2273-2280.

Tomar, N.S., Mishra, B.S. and Johari, C.B. 1966. Seasonal variations in reaction time and semen production, and prediction of some semen attributes on initial motility of spermatozoa in Hariana and Murrah bulls. Indian J. Dairy Sc., 19(1):87-93.

Ulfina, G. and Raina, V.S. 2003. Seminal attributes related to age and scrotal circumference in dairy bulls. Indian J. Dairy Sci., 56(6): 376-379.

Uysal, O., Buck, M.N., Yavas, I. and Varisli. O. 2007. Effect of various antioxidants on the Quality of frozen thawed bull semen. J. Anim. Vet. Ad., 6(12): 1362-1366.

White, I.G. 1993. Lipids and calcium uptake of sperm in relation to cold shock and preservation: a review. Reprod. Fert. Dev., 5: 639-658

Zhao, X.L., Li, Y.K., Cao, S.J., Hu, J.H., Wang, W.H., Hao, R.J. and Zan, L.S.2015. Protective effects of Ascorbic acid and Vitamin $\mathrm{E}$ on antioxidant enzyme activity of freeze-thawed semen of Qinchuan bulls. Genet. Mol. Res., 14(1): 2572-2581.

Zhao, Y. and Buhr, M.M. 1995. Cryopreservation extenders affect calcium flux in bovine spermatozoa during a temperature challenge. J. Androl., 16: 278-285.

\section{How to cite this article:}

Padamveer Singh, Sanjay Agarwal, Harjyote Singh, Satbir Singh, Pawan Kumar Verma, Mohd Shaheem Butt and Utsav Sharma. 2020. Effects of Ascorbic Acid as Antioxidant Semen Additive in Cryopreservation of Cross-bred Cattle Bull Semen. Int.J.Curr.Microbiol.App.Sci. 9(07): 3089-3099. doi: https://doi.org/10.20546/ijcmas.2020.907.364 